\title{
Fostering Awareness of Nationalism through Pancasila among High School Students
}

\author{
Soesi Idayanti1), Moh. Taufik²) \\ ${ }^{12}$ Universitas Pancasakti Tegal \\ Email: soesi_idayanti@upstegal.ac.id*)
}

\begin{abstract}
Youth and young people can play a bigger role in guarding the national development path. Various problems that arise as a result of a fading sense of nationalism and nationality have occurred recently, many young people or young people have experienced disorientation, dislocation and are involved in an interest that only cares for themselves or a certain group on behalf of the people as reasons for their activities. As the basis of the state, Pancasila must be a reference for the state in facing various global challenges in the developing world.

The purpose of this study was to determine how the role of Pancasila in fostering a sense of nationalism and patriotism among high school students in Tegal Regency and to find out how the role of the government in fostering a sense of nationalism among high school students today Type of research is the literature.

This research including library research because the data used is mostly secondary data in the form of documents related to Pancasila. The approach used in this research is philosophical. Fostering a sense of nationalism for high school students through Pancasila can be done from an early age, so that gradually with age it is hoped that a sense of nationalism will persist in the Indonesian nation. It can be started from the closest group, for example, family, because it is from the family that a sense of love for the country can be trained from an early age. Towards the younger generation, the State must be present as stipulated in the Preamble of the 1945 Constitution, the state protects all Indonesia's blood, including the young generation, high school children, where they are the young people of the nation who must be cared for and protected carefully.
\end{abstract}

Keywords: Pancasila, ideology, students, nasionalisme, nation.

\section{Introduction}

One of the problems faced by the Indonesian nation today is the waning spirit of nationalism and patriotism among the younger generation. This is due to the large number of foreign cultural influences that have entered our country, as a result of which many young people forget their own culture because they think that foreign culture is a culture that is more modern than the culture of their nation (White et al., 2020). As a result, the noble values of the nation are widely neglected and almost occur in the majority of the younger generation. Since then, now and in the future, the role of youth 
or the young generation as pillars, drivers, and guards of the course of national development is highly expected (Mihelj \& Jiménez-Martínez, 2021).

Through its broad organization and network, youth and young people can play a bigger role in guarding the national development path. Various problems that arise as a result of a fading sense of nationalism and nationalism have occurred recently, many young people or young people have experienced disorientation, dislocation and are involved in only selfish interest or a certain group on behalf of the people as a reason for their activities (Salampessy et al., 2018). Pancasila as the basis and ideology of the state is the result of the agreement of the founding fathers of the nation when the Indonesian state was founded, and until now in the era of globalization, the Indonesian state still holds fast to Pancasila as the basis of the state (Kristiono, 2017). As the basis of the state, Pancasila must be a reference for the state in facing various global challenges in the developing world (Bieber, 2020).

In this era of globalization, the role of Pancasila is of course very important to maintain the existence of the personality of the Indonesian people, because with globalization the boundaries between countries seem invisible so that various foreign cultures can easily enter society (Latif, 2018). This can have both positive and negative impacts on the Indonesian people, if we can filter the various things that arise from the impact of globalization, of course, globalization will be a positive thing because it can add insight and strengthen relations between nations and countries in the world, while negative things from the impact of globalization can damage the morale of the nation and the existence of Indonesian culture (Fu, 2019).

In connection with this, high school students especially in Tegal Regency as the young generation as pillars of the nation are expected to have a spirit of patriotism and nationalism while maintaining the cultural values of the Indonesian nation even though many foreign cultures enter the country of Indonesia (Pamungkas, 2017). Based on Pancasila, it is hoped that the influence of foreign cultures can be filtered so that the younger generation can become the generation who truly loves the Indonesian homeland regardless of their circumstances (Fadilah, 2019).

Based on exposure to the above, the formulation of the problem in this community research is how the role of Pancasila in growing sense of nationalism and patriotism among high school students? And what is the role of the government in fostering a sense of nationalism among high school students today? 


\section{Method}

This type of research is the literature, literature research is research conducted by examining secondary materials. This research includes literature research because the data used is mostly secondary in the form of legal documents. The approach used in this research is philosophical. The philosophical approach in legal research is to examine law from an ideal point of view (Syamsudin, 2019). This study uses a philosophical approach because what is being studied is the law at an ideal level.

The data source used in this research is secondary data. Secondary data is data that has been obtained indirectly or has been provided by other parties. Secondary data is used as the main reference which is readily available in the form of writing in books, scientific journals, and other written sources. Data collection techniques are carried out through conventional and online searches (Kusdarini et al., 2020). Penulusaran literature conventionally is the activity of finding library sources for data storage. Meanwhile, online writing is an activity to find library sources in cyberspace through the internet network. Literature research is conventionally carried out by searching for library materials, purchasing books, journals and attending scientific activities (seminars).

Meanwhile, online searching is done by searching the internet. The data analysis method used is qualitative. Qualitative data analysis is the process of organizing and sorting data into patterns, categories, and basic description units so that themes can be found presented in narrative form. This study uses qualitative data analysis because the data will be presented in a narrative-descriptive manner, not in numerical or numerical form.

\section{Result and Discussion}

\subsection{Result}

The Role of Pancasila in Fostering a Sense of Nationalism and Patriotism among High School Students

Pancasila comes from the word panacea which means five and sila which means foundation, joint, principles, or rules of important and good behavior. thus Pancasila is 
the five bases that contain guidelines or rules about important and good behavior. We can define Pancasila as the basic principle on which the state is based and the nation's outlook on life. A nation will not be able to stand firmly without a strong state foundation and cannot know clearly where the goal will be achieved without a view of life. With the existence of a state foundation, a nation will not be swayed in the face of problems both from within and from outside. The role and function of Pancasila in the present era are still relevant because Pancasila covers basic aspects. Besides that, Pancasila is also a tool for security and prosperity with the Indonesian people. It's just that its concrete implementation cannot be carried out properly because justice and prosperity for all Indonesian people have not been realized until now. Pancasila is also the personality of all Indonesian people. However, noble values have been very faded, eroded by behavior that only emphasizes the economic aspects of the bad globalization lifestyle. Given the very importance of Pancasila as the basis of the state, we must continue to struggle and maintain, preserve, live and practice the values of Pancasila in everyday life so that goals 3 and Pancasila can be fulfilled, so that it will be a resilience of the national identity.

\section{The basic concept of Pancasila}

Pancasila comes from the word panca which means five and sila which means foundation, joint, principles, or rules of important and good behavior. Thus Pancasila is the five foundations that contain guidelines or rules about important and good behavior. Pancasila can be interpreted as the basic lima which is used as the basis of the state and the nation's outlook on life. A nation will not be able to stand firmly without a strong state foundation and cannot know clearly where the goal will be achieved without a view of life. With the existence of a state foundation, a nation will not be swayed in the face of problems both from within and from outside.

\section{The Role and Function of Pancasila}

Pancasila as the basis of the state has meaning: (1) As the basis for administering an independent, sovereign nation, (2) As the basis for regulating the clean and authoritative administration of the state apparatus, so that the national objectives are achieved as stated in the preamble of the 4th paragraph of the 1945 constitution, and (3) As a basis, direction, and guide for the activities of the Indonesian nation in daily life.

\section{Pancasila as a Source of National Basic Law}

This term is new in the Indonesian legal system, which appeared after the reformation through the MPR decree NO. III / 1 Effendy Suryana \& Kaswan, Pancasila \& self-defense 
in the globalization era, (Bandung: Pt Refika Aditama, 2015,) pp. 153-156 4 2000, which was later amended by Law NO. 10 of 2004 concerning the formation of laws and regulations.

\section{Pancasila as the Way of Life of the Indonesian Nation}

Pancasila as a way of life means that all daily activities of the Indonesian nation must comply with the Pancasila principles because Pancasila is also a crystallization of the values that belong to and the source of the life of the Indonesian nation itself. These values are: 1) Values and spirit of divinity and religion 2) Values and spirit of humanity 3) Value and spirit of unity 4) Values and spirit of people and democracy 5) Values and spirit of social justice e. Pancasila as the Noble Covenant of the Indonesian Nation When the Indonesian nation rose to live alone as an independent nation, the Indonesian people had agreed to make Pancasila the basis of the state. The agreement was realized on August 18, 1945, by ratifying Pancasila as the 5 state bases by the Indonesian Independence Preparation Committee (PPKI) which represented the whole Indonesian nation.

\section{Pancasila as the Ideolagi of the State of Pancasila}

As a state ideology which is the common goal of the Indonesian nation which is implemented in national development, which is to create a sister and prosperous society that is equally material and spiritual based on Pancasila in the unified state of the Republic of Indonesia which is independent, sovereign, united, and sovereignty of the people in an atmosphere of a safe, peaceful nation, testing, and dynamism as well as in the world of social life that is free, friendly, secure and peaceful.

\section{Pancasila as the unifier of the nation}

As a pluralist Indonesian nation and an archipelago consisting of various islands, it is very appropriate if Pancasila is to unite the nation, this is because Pancasila has general and universal values so that it can accommodate all ethical life and can be accepted by all parties.

\subsection{Discussions}

\section{Globalization Era}

According to Setiawan, globalization is a process where events, decisions, and activities in one part of the world become a significant consequence for individuals and communities in distant areas. Globalization encourages changes that occur in several fields, such as politics, economy, social, culture, technology, defense and security, 
environment, and social life.2 2 Maulana Arafat Lubis, PPKN learning in SD / MI implementation of education a bad 21 (Medan: AKASHA SAKTI, 2018), p. 576 Globalization is a process of global social order that does not recognize boundaries. In essence, globalization is a process from which ideas are raised, then offered to be followed by other nations which eventually arrive at a point of mutual agreement and become a common guide for nations throughout the world.

The process of globalization takes place in two dimensions, namely the dimensions of space and time. Globalization seems to have been able to create interpersonal relationships in Indonesian society to become more individualistic, selfish, and pragmatic. Our society tends to be pragmatic as a result of the influence of global lifestyle problems that have penetrated their awareness of their lifestyle. Also, the understanding of nationalism has begun to decline when the state needs solidarity and unity to cooperate, a small proportion of people, especially those in the city, prioritize their groups, their groups, and even other countries compared to the interests of their country.

In the current era of globalization, every country is required to be more advanced following every progression for the sake of development, which is sometimes far from order. The parties that are fortunate in this situation, of course, are developed countries that have a much higher level of stability and capability compared to developing countries. Also, globalization can create increased relationships and dependence between nations and between people throughout humanity. As a result, it is not uncommon for many influences to enter from outside, either having positive or negative values. The development of globalization can have a big influence on the values that have developed in society. Even in a broader context, globalization can destroy existing values in society, such as socio-cultural, ideological, religious, political, and economic values.3 3 Ibid.him.159-160 71.

Politics, including developing the democratic system and the same work between countries become the development of a country 2 . Economy, marked by free trade which causes goods to no longer be original. 3. Social, including the development of social interaction in the community both in face-to-face and using social media applications such as Facebook and others. 4. Culture is characterized by the emergence of innovative arts both in language and in dance. singing, as well as culinary delights can be inherent as a characteristic of the tribes that exist in Indonesia. 


\section{The Role of the Young Generation in Globalization Based on Pancasila}

Currently, globalization is developing so rapidly, globalization affects all aspects of the life of the nation and state. Judging from the process, globalization is something natural in life that grows and develops._Here it remains how every nation and state reacts to it. If a nation is unable to keep up with the flow of globalization, especially a country with a traditional level of life and development, it will raise concerns about international relations and affect domestic conditions. For example, concerns in political, economic, social, cultural, and security aspects.

Globalization has created several opportunities that can benefit human life, including the atmosphere of life that is easier, more comfortable, practical, of quality, and works faster and more efficiently. On the other hand, globalization can pose challenges for someone. Globalization according to Chotib (2007), "globalization is essentially a phenomenon of changes in global life that can bring positive and negative influences to a nation".

So the Indonesian nation must be able to develop the professionalism of its human resources (HR) to be able to select the entry of foreign cultures that are incompatible with the national personality. 12 Globalization is a global process that affects all aspects of human life. According to Chatib (2007: 90), "for the life of the Indonesian people, the entry of foreign influences in this era of globalization is irreversible".

Globalization makes the world seem to be shrinking. Globalization brings rapid advances in information technology. Listyarti (2006: 127) argues that: Through advances in communication technology, information marketing is created that allows humans to relate to one another, learn from each other more quickly and provide information quickly and accurately. The wave of globalization has two sides, namely challenges and opportunities. In other words, there are positive and negative impacts.

The process of globalization described above can be concluded that technological advances greatly affect all aspects of life. For example, threatening the nation's culture, the fading of the national identity, and awareness of the archipelago's insight. All nations and countries that want to stand firm and strong to face the harsh problems of national and state life, must have a strong and solid-state foundation and state ideology. Ideology is a way of life of the nation is a series of value systems that live and belong to society. According to Sudarmawan (2007: 4), explains that: Because ideology is a series 
of views or value systems that live in society, ideology functions: (1) As a whole knowledge can be a basis for interpreting and interpreting the world to humans and the natural environment, (2) The basic orientation is to open insights that give meaning and show purpose in people's lives. (3) As a norm that is used as a guideline and guide for someone to step and act. (4) As a provision and a way for someone to use their ideology. As a necessity that can influence and encourage someone to carry out and achieve goals. (5) As education for a person or society to use, live up to the behavior under the orientation and norms contained therein.

To form the identity of a group or nation. It can be concluded that ideology is a set of values that are comprehensive and deep which is owned and held firmly by every society. Ideology is used by them to know how and how that is good, that is, morally or normatively considered right and fair, in behaving and behaving.

The ideology which is used as the lifeblood of the nation must be of quality and under the national personality. As explained by Alfian in Sudarmawan's book (2007: 4), three elements can be used to measure the quality of an ideology, namely: (1) Reflects the realities that live in society, meaning that ideology contains basic values that are derived from real values that live in society. (2) Reflects the quality of ideology, meaning that it is necessary to contain the ideals that a nation or state wants to achieve, namely an idealistic ideal in an ideology, for example, the ideals of nationalism, social justice, democracy, and divinity. (3) Reflects ideological flexibility, meaning that ideology's ability to influence and at the same time adapt itself to the development of society. When the Indonesian nation was about to become independent, the Indonesian nation was faced with a basic choice of state. Before Indonesia's independence, Indonesia. (4) Mempersiapkan independence by formulating Pancasila as the state. As stated by Sudarmawan (2007: 6) that: If we are going to build a house, what must be built first is the foundation or foundation. It was on this basis that the house was built. If the base is strong, the building will be strong. Likewise with the state, if the foundation is strong then the state building will be strong.

Pancasila contains values that are held by a person or a society as their way of life. The material value of Pancasila is a source of strength for the struggle of the Indonesian nation. The values contained in Pancasila are the driving force in the effort to uphold and fight for independence. Pancasila is known as the identity of the Indonesian nation. Pancasila can provide a sign or characteristic inherent in the body of society. This 
is what encourages how society thinks about the values contained in the Pancasila.

In this reform era, Pancasila seems to have no power to influence and guide the Indonesian people in the life of the nation and state. Pancasila today is no longer as popular as it was in the past. The rulers and society today seem not to care about implementing the values of Pancasila in the life of the nation and state. But here Pancasila must remain as a national ideology. Pancasila must remain the basis for solving problems faced by the Indonesian nation. As stated by Winarno (2012: 7), "By the initial initiators, Ir. Soekarno, Pancasila was extracted from Indonesia's soil and crystallized 5 of the values that developed in the lives of the various Indonesian people ".

Pancasila must be instilled or passed on to the younger generations of the Indonesian nation. it is very important to instill Pancasila values in today's young generation. Pancasila is not only instilled through formal education, but also in nonformal and informal places, such as in the family environment, community environment, and also in places in the form of foundations such as cottages or orphanages. Education is an effort to change people for the better. As is well known, children or the younger generation are assets of the nation who will continue the struggle of the Indonesian nation.

From this statement, it is clear that high school children must have a good personality. We realize that achieving behavior by the values of Pancasila is very difficult in the sense that it requires the awareness and cooperation of various parties involved in education such as the role of parents, schools or educational institutions, and the community. To realize all of this, the role of an educator or professional coach is very much needed.

\section{The role of the government in fostering a sense of nationalism among high school students today}

The spirit of nationalism and patriotism among the younger generation began to decline. This can be seen from the many young generations who think that western culture is more modern than its own culture. The younger generation, especially among university students, follow western culture rather than their own culture. This can be seen in how to behave, dress, speak to life patterns that tend to imitate foreign cultures rather than their own cultures. This happens in Hamp I $r$ all corners kata not only in big cities but has expanded to outlying villages.

Referring to Law no. 40/2009 concerning Youth, youth or youth is defined as 
"Indonesian citizens who enter an important period of growth and development, aged 16 (sixteen) to 30 (thirty) years". Meanwhile, in the demographic and anthropological context, the younger generation is divided into the preparatory age for entering the world of work, or the productive age between 15-40 years. Currently, there are 40,234,823 Indonesians who fall into the category of the younger generation. Meanwhile, from a socio-cultural point of view. The young generation from this point of view has a pluralistic character with various ethnicities, religions, economies, domiciles, and languages. They have the characteristics of a living ecosystem that is divided into fishing communities, farmers, mining, trade, offices, and so on. Meanwhile, in Article 7 and Article 8, youth services are directed at fostering patriotism, dynamics, a culture of achievement, and a spirit of professionalism; and increasing the participation and active role of youth in developing themselves, society, the nation, and the state. Whereas in Article 8, it is stated that the youth service strategy is to defend the state; youth competitions and appreciation; increase and expansion of obtaining employment opportunities.

Considering that the Unitary State of the Republic of Indonesia is a country that is different from ethnicity, culture, religion, and language. Today these differences are often used as a factor and reason to divide the Indonesian State. The differences that exist are used as material for provocation between one group and another. The waning sense of nationalism towards the nation has now also been felt. But divisions will not occur if citizens understand Bhineka Tunggal Ika, if citizens understand the meaning of Pancasila, and apply Pancasila values in the socio-cultural life of society. Such implementation efforts can be a reason for Pancasila in mandating its values in encouraging citizens to prioritize unity in differences, rather than individual and group interests that can divide the unity and unity that has been created by independent Indonesia until the age of 74 this year.

Pancasila in social and cultural applications can be done through simple things, which can be found in people's lives. With social and cultural schemes, we need to emphasize that all people understand the differences that exist in the country of Indonesia, which should now no longer need to be explained that the Indonesian state is a country with different groups. The application of Pancasila values can be started from oneself, for example by respecting and respecting religious differences, placing others as divine beings with all dignity and human rights, placing public interests above personal and group interests, upholding social society, and the attitude of life to help, kinship. and 
cooperation.

With social and cultural practices that apply the precepts in Pancasila, we can teach citizens to know and relate well to their compatriots and homeland, not easily provoked, ready to defend the country, and participate in becoming superior human resources for themselves and the Indonesian State. . Social and cultural matters are not big when compared to other state affairs. But social and cultural concerns the quality of Human Resources. By having a good relationship with the environment, superior, creative, and competitive Human Resources will be created. And it can encourage the goals of the state, namely welfare and peace towards fellow citizens. Also, the creation of quality human resources with high socio-cultural values will have a major impact on the Indonesian nation. The existence of society and culture in the community starts from their respective awareness and from a positive environment which also influences the social and cultural development of the community.

Socio-culture in Indonesia is very diverse. From one region to another, there are different cultural characteristics. From customs, beliefs, and language in communicating. Different culture has become a characteristic feature in Indonesia, the existing culture is born naturally by the environment. In culture there is pure culture and habitual culture, pure culture is a habit that has existed in the environment since someone is born, for example, for those born on the island of Java, the way of communication and accent should have been born from other areas, in Sulawesi. Meanwhile, habitual culture is an activity that is carried out repeatedly, for example in discipline. Discipline is part of character building, if disciplinary habits have been instilled from an early age and taught repeatedly, discipline will become a habitual culture. But unfortunately, now character building like this is difficult to implement. People have a habit of being century, procrastinating on work, and are not on time. Indeed, a culture of disciplinary habits can become a positive habit in people's lives, but it is indeed difficult if it is not accustomed early.

So with the different socio-culture of Indonesian society, Bhineka Tunggal Ika, the role of the state is important, by creating a conducive and pleasant space for the democratic process in Indonesia. Towards the younger generation, the State must be present as stipulated in the Preamble to the 1945 Constitution, the state protects all Indonesia's blood, including the young generation, high school children, where they are the buds of the nation who must be cared for and protected carefully. Several countries 
in the world are investing heavily in the development of the younger generation, as well as strengthening the patriotism of the young generation because by strengthening the younger generation (high school students), the country will get a bonus democracy, namely the creation of a healthy national order and supports an orderly state process. just and Prosperous.

\section{Conclusion}

Based on the description above, it can be concluded as follows. The role of Pancasila in Fostering a Sense of Nationalism and Patriotism among High School Students is very important. We realize that achieving behavior under the values of Pancasila is very difficult in the sense that it requires the awareness and cooperation of various parties involved in education such as the role of parents, schools or educational institutions, and the community. To realize all of this, the role of an educator or professional coach is very much needed.

The role of the government in fostering a sense of nationalism among high school students today with a different socio-culture of Indonesian society, Bhineka Tunggal Ika, the role of the state and government is important, by creating a conducive and pleasant space for the democratic process in Indonesia. Towards the younger generation, the State must be present as stipulated in the Preamble to the 1945 Constitution, the state protects all Indonesia's blood, including the young generation, high school children, where they are the buds of the nation who must be cared for and protected carefully.

\section{Reference}

Bieber, F. (2020). Global Nationalism in Times of the COVID-19 Pandemic. Nationalities Papers. https://doi.org/10.1017/nps.2020.35

Fadilah, N. (2019). TANTANGAN DAN PENGUATAN IDEOLOGI PANCASILA. Journal of Digital Education, Communication, and Arts, 2(2).

$\mathrm{Fu}, \mathrm{T}$. (2019). Whose global village? rethinking how technology shapes our world. $\begin{array}{llll}\text { Information, Communication } \quad \& \quad \text { Society, } & \text { 22(2). }\end{array}$ https://doi.org/10.1080/1369118x.2018.1515238

Kristiono, N. (2017). Penguatan Ideologi Pancasila Di Kalangan Mahasiswa Universitas Negeri Semarang. Harmony, 2(2).

Kusdarini, E., Sunarso, S., \& Arpannudin, I. (2020). The implementation of pancasila education through field work learning model. Cakrawala Pendidikan, 39(2). https://doi.org/10.21831/cp.v39i2.31412

Latif, Y. (2018). The religiosity, nationality, and sociality of pancasila: Toward Pancasila through Soekarno's way. In Studia Islamika (Vol. 25, Issue 2). 
https://doi.org/10.15408/sdi.v25i2.7502

Mihelj, S., \& Jiménez-Martínez, C. (2021). Digital nationalism: Understanding the role of digital media in the rise of 'new' nationalism. Nations and Nationalism, 27(2). https://doi.org/10.1111/nana.12685

Pamungkas, C. (2017). Global village dan Globalisasi dalam Konteks ke-Indonesiaan. Jurnal Global \& Strategis, 9(2). https://doi.org/10.20473/jgs.9.2.2015.245-261

Salampessy, Z., Triyuwono, I., Irianto, G., \& Hariadi, B. (2018). Pancasila paradigm: Methodology of wawasan nusantara for accounting of pancasila. Australasian Accounting, Business and Finance Journal, 12(1). https://doi.org/10.14453/aabfj.v12i1.7

Syamsudin. (2019). Pancasila Sebagai Dasar Nilai Ilmu Pengetahuan. Journal of Chemical Information and Modeling, 53(9).

White, T. J. E., Duncan, S. F., Yorgason, J. B., James, S. L., \& Holmes, E. K. (2020). Marital Interventions: Participation, Helpfulness, and Change in a Nationally Representative Sample. Family Relations, 69(1). https://doi.org/10.1111/fare.12403 